SEJ (School Education Journal)

Vol. 11 No. 3 Desember 2021

\title{
PENGEMBANGAN LEMBAR KERJA PESERTA DIDIK (LKPD) BERBASIS KETERAMPILAN BERPIKIR KRITIS PADA MATERI SISTEM EKSKRESI
}

\author{
Isnaini Hasyim Harahap, Nirwana Anas, Melfa Aisyah Hutasuhut \\ Surel: isnainihasyimhrp@gmail.com
}

\begin{abstract}
Student worksheet contains various activities that are used to facilitate and practice students' skills in learning activities. This research aims to determine the development of student worksheet based on critical thinking skills that are valid, practical, and effective on the excretory system. This is a research and development of ADDIE model. The validity of student worksheet was measured using a validation sheet. The validity of student worksheet is $78 \%$ categorized as valid. Material validity of $82 \%$ is categorized as very valid, media validity of $81 \%$ is categorized as very valid, and language validity of $71 \%$ is categorized as valid. The practicality of the student worksheet was measured using a practitioner validation sheet and student response questionnaires. The practicality of worksheet is 87\% categorized as very practical. Based on practitioner validation, the result of worksheet practicality of $89 \%$ is categorized as very practical and student response questionnaire of $85 \%$ is categorized as very practical. worksheet effectiveness was measured by normalized gain test. The control class $N$ Gain score of 0.2 is categorized as low and the experimental class N-Gain score of 0.5 is categorized as moderate.
\end{abstract}

Keywords: Effectiveness, Practicality, Critical Thinking Skills, Student Worksheet, Validity.

\begin{abstract}
ABSTRAK
Lembar kerja peserta didik (LKPD) berisi berbagai kegiatan yang digunakan untuk memfasilitasi dan melatih keterampilan berpikir peserta didik dalam kegiatan pembelajaran. Penelitian ini bertujuan untuk mengetahui pengembangan LKPD berbasis keterampilan berpikir kritis yang valid, praktis, dan efektif pada materi sistem ekskresi. Penelitian ini merupakan penelitian pengembangan model ADDIE. Validitas LKPD diukur menggunakan lembar validasi. Validitas LKPD yang dikembangkan sebesar $78 \%$ dikategorikanvalid. Validitas materi sebesar $82 \%$ dikategorikan sangat valid, validitas media sebesar $81 \%$ dikategorikan sangat valid, dan validitas bahasa sebesar $71 \%$ dikategorikan valid. Kepraktisan LKPD diukur menggunakan lembar validasi praktisi lapangan dan angket respon peserta didik. Kepraktisan LKPD yang dikembangkan sebesar 87\% dikategorikan sangat praktis. Berdasarkan validasi praktisi lapangan diperoleh kepraktisan LKPD sebesar $89 \%$ dikategorikan sangat praktis dan angket respon peserta didik sebesar $85 \%$ dikategorikan sangat praktis. Efektifitas LKPD diukur dengan uji gain ternormalisasi. Skor $\mathrm{N}$-Gain kelas kontrol sebesar 0,2 dikategorikan rendah dan skorN-Gain kelas eksperimen sebesar 0,5 dikategorikan sedang.
\end{abstract}

Kata Kunci: Efektifitas, Kepraktisan, Keterampilan Berpikir Kritis, Lembar Kerja Peserta Didik, Validitas. 

PENDAHULUAN

Kehidupan di abad 21 menuntut adanya keterampilan yang harus dimiliki oleh setiap orang khususnya peserta didik untuk mampu bertahan pada kondisi yang terus berkembang. Pembelajaran abad 21 memungkinkan peserta didik untuk mampu mengembangkan keterampilan berpikir sehingga dapat membangun pengetahuan untuk meningkatkan pemahaman terhadap materi yang dipelajari. Guru hanya berperan sebagai fasilitator, pembimbing, dan konsultan untuk memberikan stimulus, bimbingan, dan arahan kepada peserta didik dalam kegiatan pembelajaran (Trilling dan Hood, 1999). Salah satu keterampilan abad 21 adalah bepikir kritis. Berpikir kritis sebagai penilaian bertujuan dalam pengaturan diri yang menghasilkan interpretasi, analisis, evaluasi, inferensi, dan pemaparan yang menggunakan bukti, konsep, metode, kriteria, dan pertimbangan kontekstual yang menjadi dasar dalam pengambilan keputusan (Facione, 1996). Keterampilan berpikir kritis sebagai sebuah proses intelektual dapat dipelajari dan dapat dikembangkan (Wayudi, 2020). Keterampilan berpikir kritis merupakan salah satu keterampian yang wajib dalam sains oleh karena itu keterampilan berpikir kritis peserta didik harus dilatih. Keterampilan berpikir kritis peserta didik di Indonesia tergolong rendah terbukti dari hasil studi yang dilakukan PISA (Program For International Student Assessment)
Tahun 2018 yang menyatakan bahwa peserta didik Indonesia memperoleh skor dibawah rata-rata OECD dalam kategori membaca, matematika, dan sains. Secara berurut Indonesia memperoleh skor 371, 379, dan 396. Padahal skor rata-rata OECD adalah 487, 489, dan 489 (OECD, 2019). Berdasarkan hasil studi tersebut, maka perubahan pada proses pembelajaran harus dilakukan dengan merubah cara berpikir peserta didik yang tadinya berpikir pasif menjadi berpikir kritis. Keterampilan berpikir kritis peserta didik dapat dikembangkan dengan memasukkan tahapan dan indicator berpikir kritis menjadi bagian dalam kegiatan pembelajaran (Norhasanah, 2018). Jacob dan Sam (2008) menyatakan bahwa terdapat empat langkah berpikir kritis yaitu klarifikasi (clarification), asesmen (assessment), inferensi (inference), dan strategi (strategies).

Pembelajaran berbasis keterampilan berpikir kritis belum banyak diaplikasikan di sekolah begitu juga dengan instrumen yang digunakan. Salah satu instrumen yang digunakan dalam pembelajaran adalah lembar kerja peserta didik (LKPD). LKPD merupakan salah satubahan ajar yang tersusun atas lembaranlembaran yang berisi tugas yang harus dikerjakan peserta didik (Permendikbud No. 2 Tahun 2008). Lembar kerja peserta didik sebagai sumber belajar dapat dikembangkan oleh guru sebagai fasilitas yang digunakan dalam kegiatan pembelajaran (Permendikbud No. 81 
A, 2013). Lembar kerja peserta didik (LKPD) memiliki enam unsure utama yaitu (1) judul (2) petunjuk belajar (3) kompetensi dasar dan materi pokok (4) informasi pendukung (5) tugas dan langkah kerja (6) penilaian (Asmaranti, 2018). Widayantini (2013) menyatakan bahwa LKPD terdiri dari beberapa unsur (1) judul (2) mata pelajaran (3) semester (4) tempat (5) petunjuk belajar (6) kompetensi yang akan dicapai (7) indikator yang akan dicapai peserta didik (8) informasi pendukung (9) alat dan bahan untuk menyelesaikan tugas (10) langkah kerja (11) penilaian. Berdasarkan uraian tersebut.

\section{METODE PENELITIAN}

Penelitian ini menggunakan model pengembangan ADDIE yang terdiri dari lima tahapan yaitu analisis (analysis), desain (design), pengembangan (development), implementasi (implementation), dan evaluasi (evaluation)(Branch, 2009).

Penelitian dilakukan di MAN Pematangsiantar yang beralamat di Jalan Singosari Nomor 85 Komplek Syeh Abdul Jabbar Nasution, Kelurahan Bantan, Kecamatan Siantar Barat, Kota Pematangsiantar, Sumatera Utara pada 30 April s.d 29 Mei 2021. Populasi penelitian adalah seluruh kelas XI IPA MAN Pematangsiantar dan sampel penelitian terdiri dari dua kelas yaitu kelas XI IPA 5 sebagai kelas eksperimen dan XI IPA 4 sebagai kelas kontrol. Teknik pengambilan sampel yang digunakan adalah purposive sampling. Penggunaan purposive sampling didasari pada adanya pertimbangan tertentu atau seleksi tertentu dalam penentuan sampel.

\section{HASIL PENELITIAN DAN PEMBAHASAN}

Pengembangan

LKPD

berbasis keterampilan berpikir kritis dilakukan dengan menggunakan model pengembangan ADDIE yang terdiri dari lima tahapan yaitu analisis (analysis), desain (design), pengembangan (development), implementasi (implementation), dan evaluasi (evaluation). Untuk mengetahui efektivitas LKPD maka dilakukan uji gain ternormalisasi. Uji gain ternormalisasi dilakukan untuk mengetahui peningkatan keterampilan berpikir kritis peserta didik setelah diberikan perlakuan. Efektivitas LKPD diukur dari hasil pretest dan posttest kelas kontrol dan kelas eksperimen. Rekapitulasi hasil pretest dan posttest kelas kontrol dan kelas eksperimen disajikan pada tabel 11 . 
SCHOOL EDUCATION JOURNAL VOLUME 11 NO. 3 DESEMBER 2021

Tabel 1. Rekapitulasi pretest dan posttest kelas kontrol dan kelaseksperimen

\begin{tabular}{lllll}
\hline & \multicolumn{2}{c}{ Kelas Kontrol } & \multicolumn{2}{c}{ Kelas Eksperimen } \\
& Pretest & Posttest & Pretest & Posttest \\
\hline Jumlah peserta didik & 36 & 36 & 36 & 36 \\
skor rata-rata & 72,57 & 78,65 & 71,01 & 80,90 \\
nilai tertinggi & 93,75 & 100 & 100 & 100 \\
nilai terendah & 25 & 50 & 43,75 & 50 \\
\hline
\end{tabular}

Berdasarkan tabel 11 posttest kelas eksperimen sebesar diketahui bahwa rata-rata skor pretest $\quad 9,90$.

kelas kontrol adalah 72,57 dan rata- Kelas eksperimen diberikan rata skor posttest kelas kontrol adalah perlakukan berbeda dengan kelas 78,65. Maka, dapat disimpulkan kontrol yaitu kegiatan pembelajaran bahwa terdapat peningkatan skor menggunakan LKPD berbasis posttest kelas kontrol sebesar 6,08. keterampilan berpikir kritis. Rata-rata skor pretest kelas Rekapitulasi hasil pengerjaan eksperimen adalah 71,01 dan rata-rata pertanyaan penuntun pada LKPD skor posttest kelas eksperimen adalah berbasis keterampilan berpikir kritis 80,90. Maka, dapat disimpulkan disajikan pada tabel 12: bahwa terdapat peningkatan skor

Tabel 2. Rekapitulasi Hasil Pengerjaan Pertanyaan Penuntun Pada LKPD Berbasis Keterampilan Berpikir Kritis

\begin{tabular}{ll}
\hline Jumlah peserta didik & 36 \\
Total skor & 2.686 \\
Rata-rata skor & 74,61 \\
\hline
\end{tabular}

Berdasarkan tabel 12 Frekuensi dan persentase hasil diketahui bahwa total skor yang berpikir kritis peserta didik disajikan diperoleh peserta didik adalah 2.686 pada tabel 13 .

dengan rata-rata skor 74,61 .

Tabel 3. Hasil Berpikir Kritis Peserta Didik

\begin{tabular}{llrr}
\hline \multicolumn{1}{c}{ Nilai } & Kriteria & Frekuensi & Persentase \\
\hline $86-100$ & sangat kritis & 2 & $5,56 \%$ \\
$62-85$ & kritis & 31 & $86,11 \%$ \\
$38-61$ & cukup & 3 & $8,33 \%$ \\
$0-37$ & kurang & 0 & 0 \\
\hline
\end{tabular}




\begin{abstract}
Berdasarkan tabel 13 terkategori sangat kritis, 11 peserta diperoleh hasil 2 peserta didik didik terkategori kritis, 6 peserta didik terkategori sangat kritis, 31 peserta terkategori cukup kritis, dan 6 peserta didik terkategori kritis, 3 peserta didik terkategori kurang kritis dengan didik terkategori cukup kritis, dan rata-rata skor 60. Selisih skor rata-rata tidak terdapat peserta didik yang penelitian yang dilakukan dengan terkategori kurang kritis. Pertanyaan penelitian sebelumnya adalah 14,61. penuntun yang dimuat dalam lembar Perbedaan perlakuan ini kerja peserta didik (LKPD) yang telah memberikan dampak yang signifikan dikembangkan disesuaikan dengan terhadap kenaikan skor posttest kelas langkah-langkah berpikir kritis Jacob eksperimen dibandingkan dengan dan Sam. Langkah berpikir kritis kenaikan skor posttest pada kelas Jacob dan Sam terdiri dari empat kontrol. Selisih kenaikan skor posttest langkah yaitu klarifikasi, asesmen, kelas eksperimen dengan kelas inferensi, dan strategi. Berdasarkan kontrol adalah 3,82. Artinya, lembar analisis data yang telah dilakukan kerja peserta didik (LKPD) berbasis rata-rata skor yang diperoleh peserta keterampilan berpikir kritis pada didik adalah 74,61 artinya materi sistem ekskresi yang telah keterampilan berpikir kritis peserta dikembangkan dapat mengasah dan didik dikategorikan kritis. Sedangkan meningkatkan keterampilan berpikir pada penelitian Fitriana dkk (2016), kritis peserta didik.
\end{abstract} diketahui bahwa 4 peserta didik

Tabel 4. Uji Gain Ternormalisasi (N-Gain) Kelas Eksperimen

\begin{tabular}{ll}
\hline Jumlah peserta didik & 36 \\
Total skor N-Gain & 16,7 \\
Rata-rata skor N-Gain & 0,5 \\
\hline
\end{tabular}

Berdasarkan tabel 14 berada pada kategori sedang yaitu 0,3 diketahui bahwa rata-rata skor gain $\leq \mathrm{N}$-gain $\geq 0,7$.Untuk mengetahui ternormalisasi pada kelas eksperimen peningkatan keterampilan berpikir adalah 0,5. Berdasarkan kriteria gain kritis peserta didik pada kelas kontrol ternormalisasi, maka dapat maka dilakukan uji gain disimpulkan bahwa hasil skor gain ternormalisasi. ternormalisasi kelas eksperimen

Tabel 5. Uji gain ternormalisasi (N-Gain) kelas control

\begin{tabular}{ll}
\hline Jumlah peserta didik & 36 \\
Total skor N-Gain & 8,7 \\
Rata-rata skor N-Gain & 0,2 \\
\hline
\end{tabular}

Berdasarkan tabel 15 diketahui pada kelas kontrol adalah 0,2. bahwa rata-rata gain ternormalisasi Berdasarkan kriteria gain 
ternormalisasi, maka dapat disimpulkan kelas kontrol berada pada kategori bahwa hasil skor gain ternormalisasi rendah yaitu $<0,3$.

Tabel 6. Perbandingan Skor Gain Ternormalisasi Kelas Eksperimen Dan Kelaskontrol

\begin{tabular}{lll}
\hline & $\begin{array}{l}\text { Kelas } \\
\text { eksperimen }\end{array}$ & $\begin{array}{c}\text { N-Gain } \\
\text { Kelas kontrol }\end{array}$ \\
\hline Jumlah peserta didik & 36 & 36 \\
Skor N-Gain rata-rata & 0,5 & 0,2 \\
N-Gain rata-rata tertinggi & 1 & 0,5 \\
N-Gain rata-rata terendah & 0 & 0 \\
\hline
\end{tabular}

Pembahasan

Uji gain ternormalisasi dilakukan untuk mengetahui peningkatan nilai pretest dan posttest peserta didik sebelum dan setelah diberikan perlakuan. Berdasarkan hasil hasil analisis data yang dilakukan diperoleh hasil rata-rata gain ternormalisasi pada kelas eksperimen adalah 0,5 artinya skor gain ternormalisasi kelas eksperimen berada pada kategori sedang yaitu 0,3 $\leq \mathrm{N}$-gain $\geq 0,7$. Rata-rata skor gain ternormalisasi pada kelas kontrol adalah 0,2. Artinya hasil skor gain ternormalisasi kelas kontrol berada pada kategori rendah yaitu $<0,3$. Sedangkan penelitian Firdaus dan Insih (2015), diperoleh hasil bahwa skor rata-rata gain ternormalisasi pada kelas eksperimen adalah 0,35 yang berada pada kategori sedang dan 0,33 untuk kelas kontrol yang berada pada kategori sedang.

Revisi produk dilakukan pada beberapa bagian LKPD. Pada bagian sampul LKPD direvisi secara keseluruhan, yaitu dengan mengganti desain sampul LKPD, menambahkan jenjang peruntukan LKPD, dan menambahkan kata keterampilan berpikir kritis. Pada bagian awal isi LKPD, menambahkan indikator pencapaian kompetensi, memperbaiki $\mathrm{KI}$ dan KD yang disesuaikan dengan Permendikbud Nomor 37 Tahun 2018 tentang perubahan atas peraturan menteri pendidikan dan kebudayaan nomor 24 Tahun 2016 tentang kompetensi inti dan kompetensi dasar pelajaran kurikulum 2013 pada pendidikan dasar dan pendidikan menengah. Menambahkan peta konsep diawal LKPD sebelum materi pokok, menambahkan keterangan gambar dan barcode, menambahkan beberapa gambar, skema, dan video mekanisme sistem ekskresi manusia, memperbaiki kesalahan penulisan dan penggunaan bahasa, serta menambahkan beberapa materi pada organ ginjal dan gangguan pada sistem ekskresi.

\section{SIMPULAN}

Berdasarkan hasil penelitian, LKPD dikembangkan menggunakan model pengembangan ADDIE yang terdiri dari lima tahapan. Kelayakan LKPD ditinjau dari validitas, 
kepraktisan, dan efektivitasnya. Berdasarkan hasil validasi, diketahui bahwa validitas LKPD sebesar $78 \%$ yang dikategorikan valid. Kepraktisan LKPD sebesar $87 \%$ yang dikategorikan sangat praktis. Efektivitas LKPD diukur dengan uji gain ternormalisasi. Skor N-Gain kelas kontrol sebesar 0,2 yang dikategorikan rendah sedangkan skor $\mathrm{N}$-Gain kelas eksperimen sebesar 0,5 yang dikategorikan sedang.

\section{DAFTAR RUJUKAN}

Arikunto, S. 2013. Dasar-dasar Evaluasi Pendidikan, Edisi Revisi. Jakarta: BumiAksara.

Branch, R. M. 2009. Approach, Instructional Design: The ADDIE. In Department of Educational Psychology and Instructional Technology University of Georgia (Vol. 53, Issue 9).

Jacob, S. M., \& Sam, H. K. 2008. Measuring Critical thinking in Problem Solving through Online Discussion Forums in First Year University Mathematics. Lecture Notes in Engineering and Computer Science, I, 19-21.

KEMENDIKBUD RI. 2014. Permendikbud Nomor 81 A 2013. Implementasi Kurikulum Kurikulum, 1, 1-97.

Norhasanah, N. 2018. Kemampuan Berpikir Kritis Siswa SMA Dalam Pembelajaran Biologi. Jurnal Pembelajaran Biologi, 5(1), 105-110.

Peraturan Menteri Pendidikan Nasional. 2008. Salinan
Peraturan Menteri Pendidikan

Nasional Republik Indonesia Nomor 2 Tahun 2008 Tentang Buku. Jakarta: Kementerian Pendidikan dan Kebudayaan.

Purnamawati, D., Ertikanto, C., \& Suyatna, A. 2017. Keefektifan Lembar Kerja Peserta Didik Berbasis Inkuiri untuk Menumbuhkan Keterampilan Berpikir Tingkat Tinggi. Jurnal Pendidikan Fisika Al-BiRuNi 06 (2), 209-219.

Trilling, B., \& Hood, P. 1999.

Learning Technology and Education Reform in The Knowledge of We're Wired, Webbeded, and Windowe, Now What. Educational Technology Publication. 39(3), 5-18. 